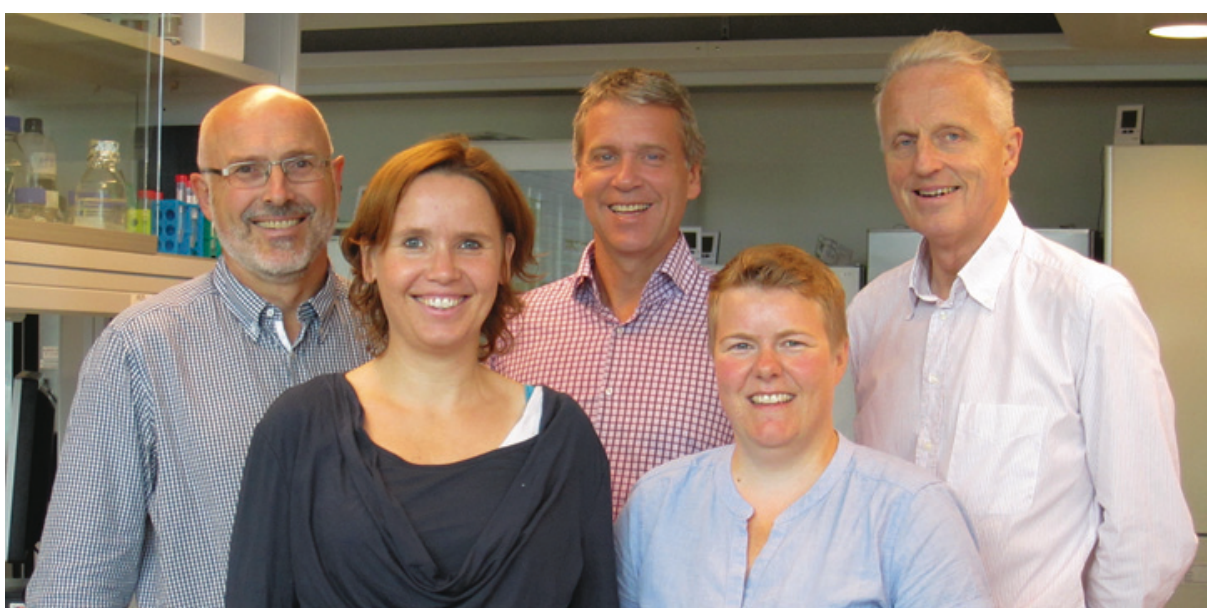

De norske forfatterne. Fra høyre: Stein Ove Døskeland, Rita Holdhus, Vidar Martin Steen, Siren Berland og Gunnar Houge

\title{
Kan utviklingshemning forårsaket av genfeil behandles?
}

En genmutasjon er vist å forårsake utviklingshemning. Funnet kan bety at velkjente medikamenter vil ha gunstig effekt hos disse pasientene.

En av cellens mest utbredte former for funksjonsregulering er gjennom fosforylering/ defosforylering. Dette er en prosess der fosfatgrupper enten bindes på eller hektes av et protein og på den måten endrer proteinets egenskaper. Proteinkinaser er en gruppe enzymer som fosforylerer, mens proteinfosfataser defosforylerer. Feil i genene som koder for proteinkinaser er kjent årsak til mange sykdommer. Hittil har kun noen få proteinfosfataser hatt kjent sykdomstilknytning. En norsk forskningsgruppe har sett nærmere på mutasjoner i gener som koder for en proteinfosfatase og funnene er publisert i The Journal of Clinical Investigation. (1)

Serin og treonin er aminosyrer som kan defosforyleres av proteinfosfatase $2 \mathrm{~A}$ (PP2A). PP2A består av tre subenheter: en katalytisk (C), en regulatorisk (B) og en strukturell (A) som bygger bro mellom B og C. Det finnes kun én type A- og C-subenhet, men mange typer B-subenheter. B-subenhetene bestemmer hva som skal defosforyleres. En av subenhetene, B56- $\delta$, er sentral i funnene til forskningsgruppen.

- Vi har funnet at mutasjoner i genet som koder for B56- $\delta$-subenheten, gir utviklingshemning assosiert med langvarig hypotoni og stort hode, sier Gunnar Houge, professor i medisinsk genetikk ved Haukeland universitetssykehus. - Disse mutasjonene blokkerer B56- $\delta$-regulert defosforylering i hjernen. Til vår overraskelse hadde visse mutasjoner i A-subenheten samme effekt. Forklaringen på dette var at A-mutasjonene også spesifikt hemmet B56- $\delta$-regulert defosforylering.

- Våre funn kan ha behandlingsmessig interesse. Noen medikamenter, som fentiaziner og multippel sklerose-medisinen fingolimod, stimulerer PP2A-defosforylering og kan potensielt ha gunstig effekt hos disse pasientene. Hvis slik behandling skulle vise seg å bedre barnas funksjonsnivå, kan arbeidet vårt ha hatt mer enn bare diagnostisk og biokjemisk interesse, sier han.

\section{Forskergruppen}

Arbeidet springer ut fra et samarbeid mellom Senter for medisinsk genetikk ved Haukeland universitetssykehus (GH, SB) og Seksjon for medisinsk genetikk ved Universitetet i Bergen (VMS, RH). Førsteforfatter foretok en syndromvurdering av indekspasienten i 2008 uten å komme frem til en diagnose. Ved hjelp av dypsekvenseringsmetodikk fant man imidlertid en mulig årsak fem år senere. Via et internasjonalt kontaktnett fant man 15 pasienter til med identiske eller overlappende mutasjoner i samme gen $(P P P 2 R 5 D)$ eller det beslektede genet $P P P 2 R 1 A$. Tidligere erfaring med proteinkinaser hjalp godt ved formulering av en hypotese om virkningsmekanisme. Denne hypotesen ble bekreftet av vår viktigste samarbeidspartner, et biokjemisk laboratorium i Belgia.

\section{Kaveh Rashidi \\ Tidsskriftet}

\section{Litteratur}

1. Houge G, Haesen D, Vissers LE et al. B56 $\delta$-related protein phosphatase 2A dysfunction identified in patients with intellectual disability. J Clin Invest 2015; 125: $3051-62$.
Ordforklaringer

Utviklingshemning: Psykomotorisk utviklingshemning, definert som IQ-nivå < 70 .

Defosforylering: Enzymatisk fjerning av fosfat grupper fra proteiner.

Nyoppståtte mutasjoner: Nyoppståtte genfeil, den vanligste årsaken til utviklingshemning.

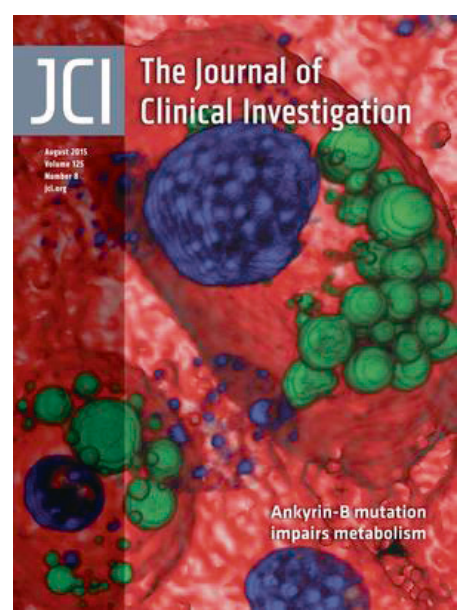

Artikkelen ble publisert i Journal of Clinical Investigation i august 2015 